\title{
Return to a Sustainable Economy Classification of Anti-Crisis Industrial Policy Measures of States in a Market Economy
}

Andrey Koshkin ${ }^{1, *}$, Matiar Rakhman Khashimi ${ }^{1}$, Arina Sharagina ${ }^{1}$, Anna Novikova ${ }^{1}$, Islam Shamsiev ${ }^{2}$

\author{
${ }^{1}$ Saint Petersburg State University, Saint-Petersburg, Russia \\ ${ }^{2}$ Peter the Great St. Petersburg Polytechnic University, Saint-Petersburg, Russia \\ ${ }^{*}$ Corresponding author. Email: koshkin_9300@mail.ru
}

\begin{abstract}
In this paper the authors make an attempt to classify the anti-crisis measures of industrial policy of national market economies in the first six months of the COVID-19 pandemic. The methodological basis of the study was the works of the St. Petersburg school of industrial policy research, developments in the field of non-hierarchical classification, as well as studies by D. Rodrik. A total of 47 measures from 9 countries were analysed. The corresponding table was constructed. The highlighted interdisciplinarity of the study allowed to draw a number of practical conclusions and to outline the further vector of research that seems promising.
\end{abstract}

Keywords: Industrial policy, Crisis management, Political management, COVID-19, Crisis.

\section{INTRODUCTION}

In recent years, the world has been dismayed by the COVID-19. The beginning of the pandemic can hardly be accepted as a period of sustainable development for the world in general or any specific national economy. On the contrary, the virus spreading turned into a fullblown crisis, which required a forthwith response from the international community and nation-states. Now we can confidently say that society is assuredly on the way to adapt to the new realities determined by the pandemic, and it is time to analyze the tested anti-crisis practices.

It seems especially relevant to examine anti-crisis measures in the area of industrial policy, which is one of the most affected by the coronavirus crisis. The way different states responded to the objective need to reduce (or to transform) citizen contacts with each other is very illustrative.

No less illustrative is the time of anti-crisis policies' starting point: the earlier a state began to implement anticrisis measures, the more mildly it could carry them out, and, therefore the less damage for the economy was done.

The next assumption is less contemplative and requires more rigorous proof: the national governments' anti-crisis measures can be classified and analyzed in terms of effectiveness.

And while the calculation of the effectiveness of specific anti-crisis strategies in the area of industrial policy can be skipped in this paper, the issue of the classification should be taken seriously and reviewed as quite relevant and important.

\section{MATERIALS AND METHODS}

The methodological foundation of this work is based on the papers of Rodrik D. [1] as one of the significant specialists in the field of development economics. Further, this article is largely based on the researches of the founder of the St. Petersburg school of industrial policy Rybakov F.F. [2], as well as on studies of nonhierarchical methods of classification at the intertheoretical level developed by Khakimov E.M. [3].

According to the framework of the research, the method of faceted classification was chosen for constructing an appropriate classification model. The complexity and diversity of anti-crisis measures taken by the different states, making this method the most suitable for the goals of this paper. Examined measures may dramatically differ in their areas, nature of impact, 
efficiency, and goals. In this case, the construction of a hierarchical classification model appears to be not only highly difficult but even hardly possible.

The empirical basis for the classification of anti-crisis industrial policy measures is the appropriate decisions of several national governments: the USA, the UK, Germany, France, Russia, Italy, India, Brazil, and Australia.

Now it is worthwhile to elaborate on the classification of anti-crisis industrial policy measures. Almost all measures have the following goals setting: they may be aimed to maintain employment or to maintain demand. Obviously, examined measures can be divided into following groups:

1) consistent and inconsistent;

2) major, medium, and minor;

3) short-, medium- and long-term.

All these criterias must be included in the classification, even though they may seem contemplative.

Further, we will necessarily be interested in the proactivity or reactivity of specific measures. Does the national government in specific cases act as a preemptive actor, or are its actions determined by the urgent need to adopt them? The government may act in two ways: only responding to current industrial sector problems, or it may attempt to predict and address the situation even before the first signs of the problem are evident. Authors believe that a fundamental difference between the government's behavior in these two situations is obvious.

Therefore, the next element of the classification exposes the specific aims of tested measures: was it the elimination of the cause of the crisis or the elimination of its negative consequences. Of course, in the implementation of the anti-crisis policy, there is a place for both approaches.

Within the topic considered in this paper, most examined measures will be aimed to eliminate the negative consequences of the COVID-19 pandemic, although the emergency mobilization of production capacity for the creation of a vaccine can be defined as a measure aimed to defeat the cause of the crisis.

The last factor in the classification can be described as the level of prior preparation of certain measures. Are these measures carried out on the basis of previously planned strategy and prepared mechanisms (for example, prescribed by law financial support for enterprises in the case of an emergency), or are they carried out according to a plan created during a crisis for the specific conditions of this particular situation?

\section{RESULTS AND DISCUSSION}

Based on the categories described above, as well as the processed empirical information, a corresponding table of the classification of anti-crisis industrial policy measures undertaken by national governments was constructed (Table 1).

Before proceeding to the interpretation of the results, it is worth mentioning that some publications of quite reliable authors have already approached the analysis of this topic. The results they obtained as part of the analysis of anti-crisis measures of the several countries are quite similar with the results of our classification [4], [5], [6]. Additionally, in the issues of proactivity and reactivity of certain anti-crisis measures, E.M. Khakimov's methodology of dialectical hierarchies had to be supplemented by the developments in the field of dialectical logic by A.V. Koshkin [7]. A wide range of dialectical correlations of the concepts of pro/reactivity allowed us to give more accurate classification results for such countries as Germany, France, and Brazil.

The correlation between proactive and reactive measures can not and should not be surprising. It is not difficult to remember how the crisis was perceived in February 2020. That time a number of national governments tried to ignore the pandemic, and simultaneously the imposition of an emergency in the U.S. was seen as something completely unbelievable. A little later, the measures themselves were seen as highly temporary. Of course, there were estimates that COVID19 did not last for more than a year or even six months, but the planning horizon was still quite close then. But, according to the well-known wise proverb "nothing is more temporary than permanent", and nothing is more permanent than temporary. As a result, the "temporary" measures have been in effect for over a year. 
Table 1.1 Anti-crisis measures during the Covid-19 pandemic.

\begin{tabular}{|c|c|c|c|c|c|}
\hline Country & Measure & Aim & $\begin{array}{l}\text { Proactivity and } \\
\text { reactivity }\end{array}$ & Scale & Consistency \\
\hline \multirow{6}{*}{ USA } & Concessional loans for enterprises & $\begin{array}{c}\text { Employment } \\
\text { maintaining }\end{array}$ & Proactive & Major & Consistent \\
\hline & One-time payments to small businesses & $\begin{array}{l}\text { Employment } \\
\text { maintaining }\end{array}$ & Reactive & Medium & Inconsistent \\
\hline & $\begin{array}{c}\text { Tax credits } \\
\text { (tax deferral, partial refund of tax deductions on wages) }\end{array}$ & $\begin{array}{c}\text { Demand } \\
\text { maintaining }\end{array}$ & Reactive & Major & Consistent \\
\hline & $\begin{array}{c}\text { Expanding unemployment benefits and social security } \\
\text { programs }\end{array}$ & $\begin{array}{c}\text { Demand } \\
\text { maintaining }\end{array}$ & Reactive & Major & Consistent \\
\hline & Tax benefits for individuals & $\begin{array}{c}\text { Demand } \\
\text { maintaining }\end{array}$ & Proactive & Medium & Inconsistent \\
\hline & Direct payments to the citizens & $\begin{array}{c}\text { Demand } \\
\text { maintaining }\end{array}$ & Reactive & Major & Inconsistent \\
\hline \multirow{5}{*}{ UK } & $\begin{array}{l}\text { Concessional loans, loan restructuring assistance, government } \\
\text { guarantees of loans }\end{array}$ & $\begin{array}{l}\text { Employment } \\
\text { maintaining }\end{array}$ & Proactive & Major & Consistent \\
\hline & 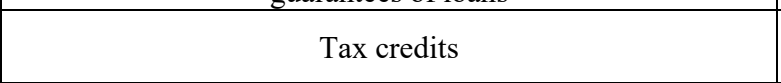 & $\begin{array}{l}\text { Employment } \\
\text { maintaining }\end{array}$ & Proactive & Medium & Inconsistent \\
\hline & Subsidizing salaries & $\begin{array}{c}\text { Employment } \\
\text { maintaining }\end{array}$ & Reactive & Minor & Inconsistent \\
\hline & Help for the self-employed & $\begin{array}{c}\text { Demand } \\
\text { maintaining }\end{array}$ & Reactive & Medium & Inconsistent \\
\hline & $\begin{array}{l}\text { Social security programs and non-insurance social protection } \\
\text { measures }\end{array}$ & $\begin{array}{c}\text { Demand } \\
\text { maintaining }\end{array}$ & Reactive & Minor & Consistent \\
\hline \multirow{5}{*}{ Germany } & Concessional loans for enterprises & $\begin{array}{l}\text { Employment } \\
\text { maintaining }\end{array}$ & Proactive & Major & Inconsistent \\
\hline & Deferral of taxes and insurance premiums & $\begin{array}{l}\text { Employment } \\
\text { maintaining }\end{array}$ & Reactive & Major & Consistent \\
\hline & Expanding unemployment benefits & $\begin{array}{c}\text { Demand } \\
\text { maintaining }\end{array}$ & Proactive & Major & Consistent \\
\hline & Social security programs & $\begin{array}{c}\text { Demand } \\
\text { maintaining }\end{array}$ & Reactive & Minor & Consistent \\
\hline & Help for the self-employed (direct payments) & $\begin{array}{l}\text { Demand } \\
\text { maintaining }\end{array}$ & Reactive & Medium & Inconsistent \\
\hline \multirow{6}{*}{ France } & Government guarantees of loans & $\begin{array}{c}\text { Employment } \\
\text { maintaining }\end{array}$ & Proactive & Major & Consistent \\
\hline & Deferral of rent payments & $\begin{array}{l}\text { Employment } \\
\text { maintaining }\end{array}$ & Reactive & Medium & Inconsistent \\
\hline & Expanding unemployment benefits & $\begin{array}{c}\text { Demand } \\
\text { maintaining }\end{array}$ & Proactive & Major & Consistent \\
\hline & Subsidizing salaries & $\begin{array}{l}\text { Employment } \\
\text { maintaining }\end{array}$ & Reactive & Major & Inconsistent \\
\hline & Social security programs & $\begin{array}{l}\text { Demand } \\
\text { maintaining }\end{array}$ & Reactive & Minor & Consistent \\
\hline & Non-insurance social protection measures & $\begin{array}{c}\text { Demand } \\
\text { maintaining }\end{array}$ & Reactive & Minor & Consistent \\
\hline \multirow{5}{*}{ Italy } & Concessional loans & $\begin{array}{c}\text { Employment } \\
\text { maintaining }\end{array}$ & Proactive & Major & Consistent \\
\hline & Tax credits & $\begin{array}{l}\text { Employment } \\
\text { maintaining }\end{array}$ & Proactive & Medium & Consistent \\
\hline & Moratorium on loan payments & $\begin{array}{c}\text { Employment } \\
\text { maintaining }\end{array}$ & Reactive & Major & Inconsistent \\
\hline & Subsidizing salaries & $\begin{array}{l}\text { Employment } \\
\text { maintaining }\end{array}$ & Reactive & Medium & Inconsistent \\
\hline & $\begin{array}{c}\text { Expansion of existing benefit programs, benefit payments for } \\
\text { workers in the hardest-hit industries }\end{array}$ & $\begin{array}{c}\text { Demand } \\
\text { maintaining }\end{array}$ & Proactive & Medium & Consistent \\
\hline
\end{tabular}

To return to the discussion of anti-crisis measures in industrial policy of specific countries, we should describe the performed analysis. During the research 9 countries and 47 specific measures were examined. The analysis allowed us to identify 22 consistent and 25 inconsistent, 16 proactive, and 31 reactive measures. Even without the use of the Pearson correlation coefficient analysis clearly demonstrates the relation between the proactivity of certain measures and its consistency. This statement can be illustrated in numbers: 14 out of 16 proactive measures with confidence should be characterized as systematic. To determine the scale factor of a measure, we had to 
Table 1.2 Anti-crisis measures during the Covid-19 pandemic.

\begin{tabular}{|c|c|c|c|c|c|}
\hline Country & Measure & Aim & $\begin{array}{l}\text { Proactivity and } \\
\text { reactivity }\end{array}$ & Scale & Consistency \\
\hline \multirow{8}{*}{ Russia } & Support for industry important enterprises & $\begin{array}{l}\text { Employment } \\
\text { maintaining }\end{array}$ & Proactive & Major & Consistent \\
\hline & $\begin{array}{l}\text { Credit vacations for businesses and interest-free loans to } \\
\text { pay salaries }\end{array}$ & $\begin{array}{l}\text { Employment } \\
\text { maintaining }\end{array}$ & Reactive & Medium & Inconsistent \\
\hline & Deferral of rent payments & $\begin{array}{c}\text { Employment } \\
\text { maintaining }\end{array}$ & Reactive & Medium & Inconsistent \\
\hline & $\begin{array}{l}\text { Payments for companies that retained most of their } \\
\text { employees }\end{array}$ & $\begin{array}{c}\text { Employment } \\
\text { maintaining }\end{array}$ & Reactive & Medium & Inconsistent \\
\hline & Payments for the self-employed & Demand maintaining & Reactive & Minor & Inconsistent \\
\hline & Expanding unemployment benefits & Demand maintaining & Reactive & Medium & Consistent \\
\hline & Paid weekends & Demand maintaining & Reactive & Minor & Inconsistent \\
\hline & Non-insurance social protection measures & Demand maintaining & Reactive & Minor & Consistent \\
\hline \multirow{4}{*}{ India } & Concessional loans & $\begin{array}{l}\text { Employment } \\
\text { maintaining }\end{array}$ & Proactive & Medium & Consistent \\
\hline & Cash payments to the poorest citizens & Demand maintaining & Reactive & Medium & Consistent \\
\hline & Social security programs & Demand maintaining & Reactive & Major & Inconsistent \\
\hline & Cancellation of certain fees & $\begin{array}{c}\text { Employment } \\
\text { maintaining }\end{array}$ & Reactive & Minor & Consistent \\
\hline \multirow{3}{*}{ Brazil } & Concessional loans, loan restructuring assistance & $\begin{array}{c}\text { Employment } \\
\text { maintaining }\end{array}$ & Proactive & Medium & Consistent \\
\hline & Deferral of tax payments & $\begin{array}{c}\text { Employment } \\
\text { maintaining }\end{array}$ & Reactive & Medium & Consistent \\
\hline & Subsidizing salaries & $\begin{array}{c}\text { Employment } \\
\text { maintaining }\end{array}$ & Reactive & Medium & Inconsistent \\
\hline \multirow{5}{*}{ Australia } & Payments to small and medium businesses & $\begin{array}{l}\text { Employment } \\
\text { maintaining }\end{array}$ & Reactive & Medium & Inconsistent \\
\hline & Concessional loans & $\begin{array}{c}\text { Employment } \\
\text { maintaining }\end{array}$ & Proactive & Major & Consistent \\
\hline & Direct payments to specific groups of the citizens & Demand maintaining & Reactive & Minor & Inconsistent \\
\hline & Tax credits & $\begin{array}{c}\text { Employment } \\
\text { maintaining }\end{array}$ & Proactive & Medium & Consistent \\
\hline & Subsidizing salaries & $\begin{array}{c}\text { Employment } \\
\text { maintaining }\end{array}$ & Reactive & Medium & Inconsistent \\
\hline
\end{tabular}

abandon absolute values and study them relative to the country's GDP. In rare cases, the measure received the "major" status because of the significant number of involved citizens.

Additionally, it should be noted that it is highly expected that the aims of described measures can be divided into two general groups: measures of demand maintaining and measures of employment maintaining. Despite the fact that the previous statement may seem to align with the ideas of Keynesian or even neo-Keynesian theories, even the fact that anti-crisis measures of national governments, rather than measures suggested by central banks, are being considered, is very illustrative. While national governments have attempted to support the economy and industry in these well-known ways, national central banks have attempted to restrain the inflation caused by these active interventions.

Inside the academic dichotomy of Keynesianism and monetarism, we have to admit that methods of state intervention, employment maintenance, and demand stimulation are essential components of anti-crisis industrial policy. After analyzing the 47 anti-crisis measures we should discuss one more intriguing thesis.
It seems that the issue of the volume of money supply in the economy appears to be very prolonged in its effect, at least in situations with standard deviations. Therefore, at the beginning of the COVID-19 pandemic, it should be taken as an inapplicable measure, even as part of anticrisis industrial policy.

Here we should repeat a crucial warning stated in the introduction. The calculation of anti-crisis actions efficiency, including monetary means, is not the topic of this paper. This thesis is a consequence of the fact that the studied measures are expectedly Keynesian in their nature. The work of national governments, which we can observe in the first six months of the pandemic, was aimed to significantly increase the volume of money supply in the economy, by injecting more and more money. More subtle monetarist instruments were hardly used in the examined period, which seems to be fruitful material for future research in this field, especially in terms of the effectiveness of specific measures.

Finally, we should justify the choice of countries that were included in the research. The accepted research strategy allowed us to focus specifically on the most extensive and strongest capitalist economies in the world. 
This framework enables authors not to examine the Chinese economy, which suffered from the COVID-19 pandemic severely, and which anti-crisis measures required to be exclusively studied by world specialists. The language limitations provided vast obstacles for authors and made an analysis of anti-crisis measures of industrial policy in Japan and South Korea hardly possible. Russia and Australia were chosen as unequal but still suitable alternatives. Such a range of countries allowed authors to include in the analysis national governments with a very different tradition of political management and, especially, crisis management.

Before conclusion, we should make a final remark about the results of the analysis. The study, which firstly seems to be utilitarian and conservative in its discipline, has proven to be appropriately interdisciplinary in the tradition of modern scholarship. For example, for an elaborated recognition of the German government's anticrisis measures, the authors of this article were helped by a linguistic study by Professor Holger Cusse of the Technical University of Dresden [8]. Measures experienced in Italy were discussed in great detail at the online conference "The Italian Corona Crisis and Its Consequences: National, Pan-European and Global Dimension", organized by the MGIMO of the Russian Federation Ministry of Foreign Affairs and the Institute of Europe of the RAS, the materials of which can be found in the scientific and analytical bulletin of the IE RAS [9]. The work of Professors Korhonen and Lyakin [10] in this area has been useful for studying the measures of the Russian government. Finally, an excellent example of interdisciplinary research, which at the same time remains on the positions of economic science, is an article performed by Professors Pashkus [11].

\section{CONCLUSION}

Based on all of the statements above, the authors of this paper can form several valid conclusions.

The first. Crisis response measures in the field of industrial policy of national governments can be classified. This question was posed back in the introduction, and its answer was bound to appear here. The challenges of such an operation undoubtedly exist, but the result of this paper shows that they can be overcomed and smoothed out by an interdisciplinary approach to the research and the developments in the field of non-hierarchical classification and dialectical logic.

The second. The correlation between the proactivity and consistency of measures is revealed. It is obvious that measures that are taken not as a forthwith reaction to the critical consequences of a crisis, but as a preparation for the coming predictable outcomes will be exactly planned and consistent. As an assumption for further research in this area, especially for the analysis of the effectiveness of anti-crisis measures of industrial policy, this thesis can be formulated. It is possible that planned and proactive measures will differ in its effectiveness.

The third. The anti-crisis measures of national governments mostly ignore the monetarist approach to generating (restoring) economic growth. Increasing the money supply in national economies, employment maintenance, and demand stimulation are the key consolidated measures of governments in this field. We can notice a rather Keynesian (or neo-Keynesian) interpretation of the issue on their part.

One last point. This seems to be a very fruitful area for further research. The not only proposed study of the effectiveness of the tested anti-crisis measures of industrial policy seems to be intriguing, but also the theory of anti-crisis management itself has received its application in a variety of aspects and conditions. The task of the scientific community is to elaborately study the experience of such horrifying cases as COVID-19 as much as possible, mainly with the use of collected empirical material.

\section{REFERENCES}

[1] D. Rodrick, Industrial Policy for the Twenty-First Century, https://vk.cc/c6tbdN.

[2] F. F. Rybakov, Industrial policy of Russia: history and modernity. SPb: Nauka, 2011, pp. 189.

[3] E. M. Khakimov, Dialectics of hierarchy and nonhierarchy in philosophy and scientific knowledge. Kazan: publishing house "Feng" of the Academy of Sciences of the Republic of Tatarstan, 2007, pp. 288.

[4] Zh. Aliaskarova, V. Pashkus, I. A. Blagikh, Proactive Industrial Policy as the Main Strategy for Improving Russia's Competitiveness in the Context of Global Economic Processes, SHS Web of Conferences, 2020.2 DOI: https://doi.org/10.1051/shsconf/20207406002

[5] V. V. Karpova, V. F. Tischenko, V. N. Ostapenko, Yu. B. Ivanov, Anti-Crisis Fiscal Measures in the European Union during the COVID-19 Pandemic and their Impact on GDP. Journal of Tax Reform. 6(3) (2020) pp. 225-243. DOI: https://doi.org/10.15826/jtr.2020.6.3.083.

[6] T. Lanshina, V. Barinova, A. Kondratyev, M.Romantsov, Sustainable Development and Digitalization: The Unusual COVID-19 Crisis Requires Original Solutions. International Organisations Research Journal, 15(4) (2020) pp. 91-114. DOI: https://doi.org/10.17323/1996-78452020-04-05 
[7] A. V. Koshkin, Dialectic horizon. SPb: Aurora, 2020, pp. 176.

[8] H. Kusse, Linguistic landscape of the corona crisis in Germany. Communication Studies, 7(4) (2020) pp. 814-845. DOI: https://doi.org/10.24147/24136182.2020.7(4).814-845.

[9] E. V. Drozhzhina, The Italian Corona Crisis and Its Consequences. Scientific and Analytical Bulletin of the Institute of Economics of the Russian Academy of Sciences, 3 (2020) pp. 108-110.

[10] I. Korhonen, A. N. Lyakin, Problems and prospects of Russia's economic growth. St Petersburg University Journal of Economic Studies, 33(1) (2017) pp. 36-50.

[11] V. Pashkus, N. Pashkus, M.Pashkus, Strategic Positioning of Territories in the Global Economy: Brand Development in Accordance with the Matrix of Competitiveness of Territories. Globalization and its Socio-Economic Consequences. 18th International Scientific Conference Proceedings. Zilina, Rajecke Teplice, Slovak Republic, 2018, pp. 2727-2734. 